\title{
PEMBELAJARAN MANDIRI MELALUI LITERASI DIGITAL
}

\author{
Abdul Haliq \\ Abdulhaliq88@gmail.com \\ Fakultas Bahasa dan Sastra, Universitas Negeri Makassar \\ Mahasiswa Program Pascasarjana Universitas Negeri Yogyakarta \\ Asih Riyanti \\ Asihriyanti17@gmail.com \\ Fakultas Keguruan dan Ilmu Pendidikan, Universitas Borneo Tarakan \\ Mahasiswa Program Pascasarjana Universitas Negeri Yogyakarta
}

\begin{abstract}
ABSTRAK
Teknologi menjadi salah satu instrumen penting untuk mendukung kegiatan belajar. Kehadiran teknologi dapat membantu guru ataupun peserta didik dalam mencapai tujuan belajarnya. Guna memanfaatkan kehadiran teknologi maka persepsi guru dan peserta didik harus berubah. Pertama, kegiatan belajar harus berpusat kepada siswa, kedua guru dan peserta didik harus bekerjasama dengan menggunakan teknologi untuk menciptakan sebuah "komunitas" yang mendidik, mendorong, dan mendukung proses pembelajaran. Proses pembelajaran yang berpusat pada siswa dengan memanfaatkan teknologi akan lebih banyak memberdayakan kemampuan siswa guna memaksimalkan potensi dirinya dalam belajar. Salah satu kegiatan belajar yang dapat dikembangkan untuk memberdayakan peserta didik dengan menggunakan teknologi adalah kegiatan belajar mandiri. Belajar mandiri dilakukan untuk mengembangkan potensi yang ada di dalam diri peserta didik sesuai dengan bakat ataupun minat dan cara belajar yang disenangi oleh peserta didik. Pemanfaatan teknologi menjadi instrument penting dalam keberhasilan belajar mandiri. Salah satu teknologi yang dapat dimanfaatkan oleh peserta didik dalam mendukung kegiatan belajar mandiri adalah literasi digital. Kegiatan literasi digital memberi peluang bagi peserta didik untuk memanfaatkan teknologi dalam mengakses dan memilah informasi yang dibutuhkan. Kegiatan literasi digital juga harus didukung kemampuan untuk melihat secara kritis informasi yang diperoleh. Pengembangan kemampuan dalam berpikir kritis menjadi salah satu aspek penting untuk memilah, menyusun, mengorganisasi, dan memanfaatkan informasi yang diperoleh guna memanfaatkan informasi tersebut untuk kebutuhan belajar. Kegiatan belajar mandiri yang didukung oleh kemampuan literasi digital dapat memberikan pengalaman baru bagi peserta didik untuk mengembangkan potensi diri. Makalah ini disusun dengan menggunakan metode studi pustaka. Kajian teori dan hasil-hasil penelitian terkait dengan pembelajaran mandiri dan literasi digital dikaji dalam maklah ini. Secara garis besar dalam makalah ini dipaparkan tentang (1) pembelajaran mandiri (2) literasi digital (3) pembelajaran bahasa melalui pembelajaran mandiri bebasis literasi digital.
\end{abstract}

Kata kunci: belajar mandiri, literasi digital, berpikir kritis.

\section{PENDAHULUAN}

Setakat ini, literasi merupakan topik yang paling hangat diperbincangkan dalam dunia akademik. BUdaya literasi dianggap mampu memberikan daya dorong yang signifikan bagi pembelajar untuk mampu bersaing secara intelektual di dunia global. Secara sederhana liteasi sering diidentikkan dengan budaya baca dan tulis. Pada awal diperkenalkan istilah literasi, hanya merujuk pada kemampuan untuk membaca dan menulis teks serta kemampuan untuk memaknai (UNESCO, 2005:148), namun seiring dengan perkembangan, istilah literasi mulai merambah keberbagai hal. Istilah literasi bahkan digunakan untuk semua disiplin ilmu, dan disesuaikan dengan disiplin ilmu yang menggunakan istilah literasi tersebut. Salah satu istilah literasi jika dikaitkan dengan dunia digital yaitu istilah literasi digital. Konsep literasi ini mulai muncul sejak tahun 1990. Salah satu tokoh terkenal yakni Gilster (dalam Riel, et. al. 2012: 3) yang mendefinisikan literasi digital sebagai suatu kemampuan untuk memahami dan menggunakan informasi dari berbagai sumber digital.

Konsep literasi digital sangat erat dengan penggunaan media digital, dalam hal ini penggunaan media internet. Penggunaan media internet belakangan ini menjadi kebutuhan dalam setiap aktivitas yang menuntut pemerolehan informasi yang begitu cepat. Internet yang menyediakan akses informasi yang cepat dan senantiasi terperbaharuai setiap saat. Untuk itu, akses terhadap informasi sangat dibutuhkan dalam rangka memperbaharui informasi yang diperoleh. 
Banyaknya informasi yang beredar di dunia internet, menuntut seseorang untuk mampu membedakan dan mengurutkan informasi yang baik dan tidak baik. Informasi yang ada di internet pada dasarnya tidak semuanya memiliki niai kebenaran atau kebaikan. Beberapa informasi bahkan merupakan informasi yang tidak benar adanya atau lazimnya dikenal dengan informasi hoax. Hoax adalah informasi sesat dan berbahaya karena menyesatkan persepsi manusia dengan menyampaikan informasi palsu sebagai kebenaran (Rasywir dan Purwarianti, 2015). Pemahaman dan penggunaan literasi digital dengan baik dapat menghindarkan penggunan internet pada informasi hoax dan lebih menekankan pada informasi yang benar dan baik sesuai dengan kebutuhan pengguna.

Jika dilihat uraian di atas, literasi digital cenderung merujuk pada kemampuan individu dalam menggunakan pengetahuannya untuk memanfaatkan informasi dan sekaligus menyampaikan informasi dengan memanfaatkan media literasi digital. Kegiatan yang bersifat individual ini juga diidentikkan dengan kegiatan mandiri. Jika dihubungkan dengan pembelajaran maka kegiatan ini juga disebut sebagai kegiatan belajar mandiri. Kegiatan belajar mandiri merupakan kegiatan belajar yang dilakukan oleh peserta didik secara mandiri dalam mencapai tujuan belajarnya dan tidak bergantung pada orang lain. Menurut Hiemstra (1994:1) pengertian belajar mandiri adalah sebagai berikut:

1. Setiap individu berusaha meningkatkan tanggung jawab untuk mengambil berbagai keputusan.

2. Belajar mandiri dipandang sebagai suatu sifat yang sudah ada pada setiap orang dan situasi pembelajaran.

3. Belajar mandiri bukan berarti memisahkan diri dengan orang lain

4. Dengan belajar mandiri siswa dapat mentransfer hasil belajarnya yang berupa pengetahuan dan keterampilan ke dalam situasi yang lain

5. Siswa yang melakukan belajar mandiri dapat melibatkan berbagai sumber daya dan aktivitas, seperti membaca sendiri, belajar kelompok, latihan-latihan, dialog elektronik, dan kegiatan korespondensi

6. Peran efektif guru dalam mengajar mandiri masih dimungkinkan, seperti diaog dengan siswa, pencarian sumber, mengevaluasi hasil, dan memberi gagasan-gasan kreatif

7. Beberapa institusi pendidikan sedang mengembangkan gagasan belajar mandiri menjadi program yag lebih terbuka sebagai alternatif pembelajaran yang bersifat individual dan program-program inovatif lainnya.

Pembelajaran mandiri dimaksudkan untuk membangun budaya belajar yang dikonstruk dari peserta didik itu sendiri. Inisiatif serta tujuan belajar, dan juga cara belajar ditentukan oleh peserta didik sendiri. Hal ini dapat dilakukan oleh tenaga pendidik untuk mengarahkan peserta didik dalam mengembangkan kemampuan belajar siswanya. Pendidik yang baik adalah pendidik yang mampu meningkatkan pemberdayaan anak didiknya sehingga mereka mampu belajar dengan efektif (Suardana, 2012). Tenaga pendidik memiliki peran yang sangat sentral dalam meningkatkan permberdayaan peserta didik. Karena betapapun guru dan dosen dapat memperbaiki hasil belajar anak didiknya dengan menggunakan model, pendekatan, dan metode mengajar yang tepat sesuai dengan tujuan pembelajaran dalam kurikulum tetapi mereka belum mampu secara optimal menciptakan kondisi sehingga anak didik bisa belajar dan bagaimana belajar (Chaeruman, 2007). Untuk itu salah satu cara yang dapat ditempuh untuk meningkatkan pemberdayaan peserta didik yaitu dengan mengembangkan kemandirian anak dalam belajar.

\section{PEMBAHASAN}

\section{Pembelajaran Mandiri}

Pembelajaran mandiri merupakan pembelajaran yang mengoptimalkan atau memperdayakan potesi mahasiswa dalam proses belajar yang dilakukan secara individu. Definisi ini berkaitan dengan definisi oleh salah satu model pembelajaran mandiri yang biasa disebut sebagai Self-Directed Learning (SDL). Melalui penerapan SDL peserta belajar diberikan otonomi dalam mengelola belajarnya yang nantinya mengarah pada kemandirian belajar. Otonomi mahasiswa dalam SDL secara garis besarnya mencakup (1) planning, (2) monitoring, dan (3) evaluating (Mok \& Lung, 2005; Chaeruman, 2007; Sunarto, 2008). Model SDL menyadarkan dan memberdayakan mahasiswa sebagai pebelajar usia dewasa, yaitu belajar adalah tanggung jawab mereka sendiri sehingga proses belajar yang dilakukan juga optimal yang berimbas pada peningkatan proses dan hasil belajar. Hal ini sejalan dengan pernyataan Sunarto (2008) yang menyatakan bahwa jika seseorang memiliki peluang untuk mengembangkan kemandirian belajarnya secara maksimal, maka dia akan dapat mengelola belajarnya dengan baik sehingga hasil yang nantinya didapatkan akan optimal. Peran pengajar dalam pembelajaran hanya sebagai fasilitator dan mediator (Slavin, 1995; Suarni, 2005; Song \& Hill, 2007; dalam Sunarto, 2008). 
Hasil penelitian yang dilakukan Hyland \& Kranzow (2011) mengungkapkan bahwa SDL memberi pengaruh positif terhadap performa akademik pada mahasiswa tingkat pendidikan sarjana dan pascasarjana. Pada model SDL, mahasiswa memiliki inisiatif, dengan atau tanpa bantuan orang lain untuk menganalisis kebutuhan belajarnya sendiri, merumuskan tujuan belajarnya sendiri, mengidentifikasi sumber-sumber belajar, memilih dan melaksanakan strategi belajar yang sesuai serta mengevaluasi hasil belajarnya sendiri (Knowles, dalam Zulharman, 2010). Model SDL lebih menekankan pada keterampilan, proses, dan sistem dibandingkan dengan pemenuhan isi dan tes.

Pembelajaran mandiri dalam hal ini yang merupakan model pembelajaran SDL tentu harus didukung oleh yang lain. Pembelajaran mandiri akan sangat bermanfaat untuk pemberdayaan kompetensi mahasiswa yang juga selanjutnya merupakan pengembangan diri mahasiswa berdasarkan keinginan dan tujuan belajar yang ditetapkan oleh setiap mahasiswa. Namun demikian, pembelajaran mandiri dengan model SDL ini tentu harus didukung oleh kegiatan yang lain guna mengefektifkan kegiatan belajar mandiri yang dicanangkan oleh setiap mahasiswa. Pembelajaran dengan model SDL efektif dilakukan jikan dikombinasikan dengan konteks pendidikan berbasis online (Bracey, 2010). Pendidikan berbasis online yang dimaksudkan dalam tulisan ini adalah kegiatan literasi digital guna mendukung keberlangsungan model SDL yang digunakan oleh mahasiswa.

\section{Lietrasi Digital}

Istilah literasi digital mengacu pada praktik membaca, menulis, dan komunikasi yang dimungkinkan melalui media digital (Hafner, dkk., 2015). Komunikasi yang dilakukan melalui media digital bukanlah komunikasi biasa. Melainkan melibatkan cara berpikir yang dapat melihat secara objektif baik informasi yang diperoleh maupun informasi yang dikomun ikasikan kepada khalayak. Hal ini dikemukakan oleh Eshet (dalam Eshet, 2004) yang menekankan bahwa literasi digital seharusnya lebih dari sekedar kemampuan menggunakan berbagai sumber digital secara efektif, namun demikian istilah literasi digital juga merupakan sebentuk cara berpikir tertentu.

Salah satu peneliti yang juga berkonsentrasi pada kegiatan literasi digital, Bawden (2001) menawarkan pemahaman baru mengenai literasi digital yang berakar pada literasi komputer dan literasi informasi. Berbasis pada literasi komputer dan informasi, Bawden (2001) menyusun konsep literasi digital. Lebih komprehensif dibandingkan Glitser (1997), Bawden, (2001) menyebutkan bahwa digital literasi menyangkut beberapa aspek berikut ini.

1. Perakitan pengetahuan yaitu kemampuan membangun informasi dari berbagai sumber yang terpercaya.

2. Kemampuan menyajikan informasi termasuk di dalamnya berpikir kritis dalam memahami informasi dengan kewaspadaan terhadap validitas dan kelengkapan sumber dari internet.

3. Kemampuan membaca dan memahami materi informasi yang tidak berurutan (nonsequential) dan dinamis.

4. Kesadaran tentang arti penting media konvensional dan menghubungkannya dengan media berjaringan (internet).

5. Kesadaran terhadap akses jaringan orang yang dapat digunakan sebagai sumber rujukan dan pertolongan.

6. Penggunaan saringan terhadap informasi yang datang.

7. Merasa nyaman dan memiliki akses untuk mengomunikasikan dan mempublikasikan informasi.

Jika menilik pendapat Bawden (2001) di atas maka digital literasi lebih banyak dikaitkan dengan keterampilan teknis mengakses, merangkai, memahami dan menyebarluaskan informasi. Pendapat berbeda disampaikan oleh Buckingham (2007) yang mengikuti pola komponen-komponen literasi media yang sebelumnya telah berkembang luas. Ia menyatakan bahwa digital literasi juga berkaitan dengan empat komponen penting yaitu: representasi, bahasa, produksi dan khalayak. Satu per satu akan dibahas berikut ini (Buckingham, 2007: 47 - 49).

1. Representasi: sebagaimana media lain, media digital merepresentasikan dunia bukan semata-mata merefleksikan dunia itu sendiri. Beberapa bagian dalam media digital adalah hasil intrepretasi dan seleksi atas kenyataan.

2. Bahasa: individu tidak saja dituntut mampu berbahasa namun juga memahami aneka kode dan konvensi pada berbagai genre konten. Hal ini membutuhkan kemampuan untuk memahami berbagai retorika fungsi bahasa seperti persuasi, eufimisme, hiperbola dsb.

3. Produksi: literasi juga berkaitan dengan pemahaman mengenai siapa yang berkomunikasi kepada siapa dan mengapa. Hal ini berkaitan dengan motif komunikasi sehingga khalayak dapat memahami 'keamanan' konten. 
4. Khalayak: hal ini terkait dengan posisi khalayak yaitu pemahaman tentang bagaimana media menempatkan, menarget dan merespon khalayak termasuk di dalamnya cara-cara media digital mendapatkan informasi dari khalayak berkaitan dengan isu privasi dan keamanan pengguna.

Topik-topik literasi digital yang disampaikan oleh Buckingham (2007) menekankan pemahaman konten digital dan kemampuan khalayak memeriksa keamanan dan privasi penggunaan media digital. Pandangan lain dikemukakan oleh Martin (2008) yang menyatakan bahwa literasi digital merupakan gabungan dari beberapa bentuk literasi yaitu: komputer, informasi, teknologi, visual, media dan komunikasi. Menilik enam ketrampilan literasi dasar tersebut, komputer, informasi, teknologi, media, komunikasi dan visual, maka Martin (2008) merumuskan beberapa dimensi literasi digital berikut ini.

1. Literasi digital melibatkan kemampuan aksi digital yang terikat dengan kerja, pembelajaran, kesenangan dan aspek lain dalam hidup sehari-hari.

2. Literasi digital secara individual bervariasi tergantung situasi sehari-hari yang ia alami dan juga proses sepanjang hayat sebagaimana situasi hidup individu itu.

3. Literasi digital lebih luas dari literasi teknologi komunikasi informasi.

4. Literasi digital melibatkan kemampuan mengumpulkan dan menggunakan pengetahuan, teknik, sikap dan kualitas personal selain itu juga kemampuan merencanakan, menjalankan dan mengevaluasi tindakan digital sebagai bagian dari penyelesaian masalah/tugas dalam hidup.

5. Literasi digital juga melibatkan kesadaran seseorang terhadap tingkat literasi digitalnya dan pengembangan literasi digital.

Lebih lanjut Martin (2008) mengemukakan bahwa literasi digital merupakan kompetensi yang berjenjang sebagaimana diungkapkan oleh Mayes dan Fowler (2006). Pada literasi digital tingkat satu, kompetensi digital, seseorang harus menguasai kemampuan dasar, konsep, pendekatan dan tindakan ketika berhadapan dengan media digital. Pada tingkat dua, penggunaan digital, seseorang dapat menerapkan aplikasi untuk tujuan produktif/profesional misalnya menggunakan media digital untuk bisnis, pengajaran, kampanye sosial dsb. Sedangkan di tingkat teratas, transformasi digital, seseorang mampu menggunakan media digital untuk melakukan inovasi dan kreatifitas bagi masyarakat luas.

Penggunaan media digital sangat dimungkinkan dalam proses pembelajaran, terlebih pada kegiatan belajar mandiri (SDL). Pemanfaatan konten-konten digital oleh mahasiswa tentu harus didukung oleh kompetensi penggunaan alat-alat digital dalam mengakses informasi, kompetensi untuk memilah informasi yang tidak berurutan (nonsequential), kompetensi berpikir kritis dalam menelaah informasi yang diperoleh, dan kompetensi mengomunikasikan tulisan yang dihasilkan. Kompetensi ini akan sangat mendukung proses pembelajaran dengan mkodel SDL dalam memanfaatkan literasi digital sebagai sarana dalam mengelola dan mengomunikasinkan tulisan yang dihasilkan.

Terkait dalam pembelajaran bahasa, terdapat dua keterampilan berbahasa yang menjadi tuntutan wajib, yaitu keterampilan yang bersifat reseptif dan produktif. Keterampilan reseptif yaitu keterampilan menyimak dan membaca, sedangkan keterampilan produktif yaitu keterampilan berbicara dan menulis. Kegiatan rseptif merupakan kegiatan pengumpulan informasi yang selanjutnya digunakan untuk kebutuhan keterampilan produktif. Sebagai contoh, untuk menghasilkan tulisan yang baik dan berkualitas maka perlu dukungan referensi yang berkualitas pula. Kemampuan mengelola informasi dari sumbersumber digital yang dapat dimanfaatkan sebagai referensi akan sangat berperan dalam menghasilkan tulisan yang baik. Pemanfaatan sumber-sumber referensi berbasis digital ini dikenal sebagai kegiatan literasi digital. Untuk itu perlu dikemas dengan baik, suatu model pembelajaran yang memberdayakan kemampuan mahasiswa dan memanfaatkan sumber-sumber informasi berbasis digital dalam pembelajaran. Dalam hal ini pembelajaran bahasa melalui pembelajaran mandiri berbasis literasi digital perlu dikembangkan guna meningkatkan kompetensi mahasiswa dalam mengakses dan mengomunikasikan tulisan-tulisan yang berkualitas.

\section{Pembelajaran Bahasa melalui Pembelajaran Mandiri Bebasis Literasi Digital}

Berdasarkan hasil penelitian, bahwa SDL lebih sering diuji dalam konteks pendidikan berbasis online (Bracey, 2010). Menurut Biggs (2003) perkembangan ilmu pengetahuan dan teknologi akan memberi kontribusi terhadap peningkatan keterampilan SDL manusia. Melalui pemanfaatan teknologi dan perangkat digital, individu diberikan ruang untuk mengembangkan keterampilan SDL melalui berbagai kegiatan dan sumber daya yang ada seperti partisipasi dalam kelompok belajar online, kegiatan menulis reflektif serta dialog online (Hiemstra, 1994). Hasil penelitian juga menunjukkan bahwa terdapat korelasi positif antara SDL dengan performa belajar pada peserta didik yang belajar dalam lingkungan berbasis online (Chou \& Chen dalam Hyland \& Kranzow, 2011). 
Di era digital seperti sekarang ini, belajar mandiri bukan lagi menjadi masalah. Sumber-sumber referensi atau bahan kuliah dapat dengan mudah diakses dan diperoleh melalui media internet. Fenomena ini memunculkan sumber referensi ilmiah yang tersedia dalam bentuk digital dan bisa diakses untuk mendapatkan jutaan bahkan milyaran sumber informasi yang berguna untuk perkuliahan (Hanum, 2014). Perkembangan teknologi ini, memungkinkan mahasiswa untuk bisa mengakses semua informasi dari dalam negeri maupun luar negeri, yang bertaraf nasional ataupun internasional. Semakin banyak sumber belajar yang dimiliki mahasiswa, maka bisa membantu proses kelancaran belajarnya sehingga mempercepat masa studinya (Setiyani, 2010).

Pembelajaran bahasa, khususnya pembelajaran bahasa Indonesia menjadi salah satu yang dapat dimanfaatkan guna mengembangkan keterampilan literasi mahasiswa. Terlebih kegiatan literasi sangat identik dengan keterampilan berbahasa yaitu keterampilan membaca dan menyimak (reseptif) serta keterampilan menulis dan berbicara (produktif). Penjelasan yang dikembangkan secara konseptual dan berdasarkan hasil penelitian di atas telah mendudukkan literasi digital dan model pembelajaran mandiri (SDL) secara jelas. Keterampilan literasi digital ini dapat dimanfaatkan mahasiswa dalam mengakses, memahami, menyebarluaskan, dan membuat informasi dalam konten digital. Keterampilan literasi digital dapat dimanfaatkan dalam konteks belajar mandiri untuk aktivitas produktif seperti menulis ataupun untuk kebutuhan membaca (reseptif). Meski pada dasarnya kebutuhan akan menghasilkan tulisan yang baik harus didukung oleh kegiatan membaca yang baik pula. Sehingga kegiatan belajar mandiri yang ditopang oleh keterampilan literasi digital yang mumpuni sangat dibutuhkan dalam pembelajaran bahasa Indonesia.

Dalam pembelajaran bahasa Indonesia, keterampilan berbahasa (menyimak, berbicara, membaca, dan menulis) menjadi kompetensi yang wajib dikuasai oleh mahasiswa. Jika dihubungkan dengan literasi digital maka ketrampilan membaca, menyimak dan menulis dilakukan dengan media digital. Mahasiswa dapat mengembangkan keterampilan berbahasa secara mandiri melalui bantuan konten-konten digital yang dapat diakses oleh setiap individu. Pembelajaran bahasa dapat memberikan keterampilan tambahan kepada mahsiswa guna mengenali konten-konten informasi yang bersifat hoax dan ilmiah. Keterampilan ini sangat berguna untuk mendukung kegiatan literasi digital oleh mahasiswa yang dilakukan secara mandiri.

\section{KESIMPULAN \& SARAN}

Berdasarkan urain di atas, dapat disimpulkan bahwa:

1. Pembelajaran mandiri merupakan pembelajaran yang dilakukan guna mengoptimalkan dan memberdayakan kompetensi mahasiswa yang dilakukan secara individu.

2. Litrasi digital merupakan keterampilan mengakses, memilah, dan mengomunikasikan informasi melalui konten digital.

3. Pembelajaran bahasa dapat dikembangkan dengan model pembelajaran mandiri (SDL) dengan memanfaatkan keterampilan literasi digital untuk mengembangkan keterampilan berbahasa melalui konten-konten digital.

Dari kesimpulan tersebut, maka diajukan saran seperti berikut:

1. Pembelajaran mandiri perlu digalakkan guna mengembangkan dan sekaligus meperdayakan kompetensi setiap mahasiswa.

2. keterampilan literasi digital di era digital seperti sekarang ini wajib dikembangkan oleh setiap mahasiswa guna memudahkan mahasiswa dalam mengakses, memilah, dan mengomunikasikan informasi melalui media digital.

3. Pembelajaran bahasa sebaiknya menggunakan pembelajaran mandiri (SDL) yang didukung dengan kegiatan literasi digital guna mengembangkan keterampilan berbahasa mahasiswa.

\section{DAFTAR PUSTAKA}

A. Hafner, Christoph, Alice Chik, \& Rodney H. Jones. 2015. Digital Literacies and language learning. Journal: Language Learning \& Technology. October 2015, Volume 19, Number 3. Diakses tanggal 2 April 2018. http://lit.msu.edu/issues/october2015/commentary.pdf

Bawden, D. (2001). Information and digital literacies: a review of concepts. Journal of documentation, 57(2), 218-259. Diakses pada tanggal 18 Febaruari 2018. https://arizona.openrepository.com/bitstream/handle/10150/105803/bawden.pdf;jsessionid=AB74 D57F437985EC8DF48D6343BC7B3A?sequence $=1$. 
Biggs, J. (2003). Teaching for Quality Learning at University Second edition. Buckingham: The Society for Research into Higher Education and Open University Press.

Bracey, P. 2010. Self-directed learning vs. Self-regulated learning : twins or just friends. Departemen of learning technologies, college of information University of North Texas, e-learn world conference. Diaksespada tanggal 20 Februari 2018. www.learntechlib.org/d/35780

Buckingham, D. 2007. Digital Media Literacies: rethinking media education in the age of the Internet. Research in Comparative and International Education, Volume 2, Number 1, 2007, 43-55.

Diakses pada tanggal 18 Februari 2018. http://journals.sagepub.com/doi/pdf/10.2304/rcie.2007.2.1.43

Chaeruman, U. A. 2007. Suatu Pendidikan Dengan Sistem Belajar Mandiri. Jurnal Teknologi Pendidikan, $6(2): 7-37$.

Eshet-Alkalai Y. 2004. Digital Literacy: A Conceptual Framework for Survival Skills in the Digital Era. Journal: Journal of Educational Multimedia and Hypermedia (2004) 13(1),93-106. Diakses pada tanggal 20 Februari 2018. https://www.openu.ac.il/personal_sites/download/Digital-literacy2004JEMH.pdf

Hiemstra, R. (1994). Self Directed learning. Diakses pada tanggal 10 Februari 2018 dari: ccnmtl.columbia.edu/projects/pl3p/Self-Directed\%20Learning.pdf

Hyland, N \& Kranzow, J. 2011. Faculty And Student Views Of Using Digital Tools To Enhance SelfDirected Learning And Critical Thinking.International Journal of Self-Directed Learning Volume 8, Number 2, Diakses pada tanggal 20 Februari 2018 dari: sdlglobal.com/IJSDL/IJSDL8.2.pdf

Martin, Allan. (2008). Digital Literacy and the 'Digital Society' dalam Lankshear, C and Knobel, M (ed). Digital literacies: concepts, policies and practices. Die Deutsche Bibliothek

Rasywir dan Purwarianti, 2015. Eksperimen pada Sistem Klasifikasi Berita Hoax Berbahasa Indonesia Berbasis Pembelajaran Mesin. Journal: Cybermatika Vol. 3 No. 2 Desember 2015. Diakses pada tanggal 20 Februari 2018.

http://cybermatika.stei.itb.ac.id/ojs/index.php/cybermatika/article/view/133/65

Setiyani, R. (2010). Pemanfaatan Internet Sebagai Sumber Belajar. Jurnal Pendidikan Ekonomi Dinamika Pendidikan Fakultas Ekonomi UNNES.Diakses pada tanggal 18 Februari 2018 dari : journal.unnes.ac.id

Suardana, I Kade. 2012. Implementasi model belajar mandiri untuk Meningkatkan aktivitas, hasil, dan Kemandirian belajar mahasiswa. Jurnal Pendidikan dan Pengajaran, Jilid 45, Nomor 1, April 2012, hlm.56-65. Diakses pada tanggal 20 Februari 2018. file:///C:/Users/Haliq/Downloads/17853235-1-SM\%20(2).pdf

Sunarto. 2008. Kemandirian belajar. Diakses pada tanggal 18 Februari 2018. http://banjarnegarambs.wordpress.com/kemandirianbelajar-siswa/.

UNESCO.2005. Education for All : Literacy for Life. diakses pada tanggal 8 Februari 2018 http://www.uis.unesco.org/Library/Documents/gmr06-en.pdf.

Zulharman. 2008. Self-Directed Learning. online. Diakses pada tanggal 20 Februari 2018. http://zulharman79.word press.com/2008/05/14/self-directed-learning-sdl-atau-belajar$\underline{\text { mandiri.htm }}$ 


\section{RIWAYAT HIDUP/CURRICULUM VITAE}

Nama/Complete Name

Institusi/Institution

Pendidikan/Education

Minat Penelitian/Research Interest
: Abdul Haliq

: Fakultas Bahasa dan Sastra Universitas Negeri

Makassar/Program Pascasarjana Universitas Negeri Yogyakarta

: S2 Pendidikan Bahasa dan Sastra Indonesia

: Pembelajaran Bahasa dan Sastra Indonesia

\begin{tabular}{|l|l|l|l|}
\hline \multicolumn{1}{|c|}{$\begin{array}{c}\text { Nama Lengkap/ } \\
\text { Complete Name }\end{array}$} & \multicolumn{1}{|c|}{$\begin{array}{c}\text { Institusi/ } \\
\text { Institution }\end{array}$} & \multicolumn{1}{|c|}{$\begin{array}{c}\text { Pendidikan/ } \\
\text { Education }\end{array}$} & \multicolumn{1}{c|}{$\begin{array}{c}\text { Minat Penelitian/ } \\
\text { Research Interests }\end{array}$} \\
\hline Asih Riyanti & $\begin{array}{l}\text { Fakultas Keguruan dan } \\
\text { Ilmu Pendidikan } \\
\text { Universitas Borneo } \\
\text { Tarakan/ Program } \\
\text { Pascasarjana } \\
\text { Universitas Negeri } \\
\text { Yogyakarta }\end{array}$ & $\begin{array}{l}\text { S2 Pendidikan Bahasa } \\
\text { Indonesia }\end{array}$ & $\begin{array}{l}\text { Pembelajaran Bahasa } \\
\text { dan Sastra Indonesia }\end{array}$ \\
\hline & & & \\
\hline & & & \\
\hline
\end{tabular}

Format tabel digunakan jika Pemakalah lebih dari satu orang 